\title{
Estimation of the amount of erosion at unconformities in the last stage of the Eocene Sanduo period in the Subei Basin, China
}

\author{
Chen Liqiong* \\ Jiangsu Oilfield Company, SINOPEC, Jiangsu 225009, China
}

\begin{abstract}
Strata erosion is a widespread phenomenon in sedimentary basins. The generation, migration, and accumulation of hydrocarbon is influenced by the scale of erosion, so estimating the amount of erosion is essential in the analysis of oil and gas bearing basins. According to the geological features in the Subei Basin and the actual data, using the integrated method, we estimated the level of erosion at the unconformities caused by the Sanduo event. By using the mudstone interval transit time method and the vitrinite reflectance method on data from typical wells, it can be concluded that the Gaoyou, Jinhu, and Hongze depressions suffered strong strata erosion from the late Eocene to Oligocene, and the total strata erosion thickness was 300-1,100 m. Different tectonic units in the same depression have extremely uneven erosion intensity: the low convex regions have the maximum erosion thickness, amounting to 800-1,100 m; the slope regions have an erosion thickness of generally $600-800 \mathrm{~m}$; the erosion thickness of the slope-hollow transition zone is $300-500 \mathrm{~m}$. For the whole basin, we used the strata thickness trend analysis method combined with the interval transit time and vitrinite reflectance methods to estimate the erosion thickness in the Sanduo period. The results show that the most severe erosion of the Sanduo event in the Subei Basin is between 1,000 m to $1,200 \mathrm{~m}$, mainly located in depressions around the Jianhu Uplift; the deep hollow area has the least erosion, generally about 300-600 m, and the erosion in the slope area is about $600-900 \mathrm{~m}$. Compared with the northern part, the southern part has relatively little erosion. It is also proved that the Sanduo movement has heterogeneous intensity, and the western region has greater intensity than the eastern region.
\end{abstract}

Key words: Unconformity, estimation of erosion, mudstone interval transit time method, vitrinite reflectance method, Subei Basin

\section{Geological background}

The Subei Basin is located in the back-arc area of the Mesozoic and Cenozoic tectonic domain of the Western Pacific, part of the Yangtze structure-sedimentary section, and the regional area is about $3.54 \times 10^{4} \mathrm{~km}^{2}$. The main developed formations are as follows: Quaternary Dongtai Formation (Qd) (0-2 Ma), Neogene Yancheng Formation $\left(\mathrm{N}_{2} \mathrm{y}\right)(2-24.6$ $\mathrm{Ma})$, Eogene Sanduo Formation $\left(\mathrm{E}_{2} \mathrm{~s}\right)$ (38-50.5 Ma), Dainan Formation $\left(E_{2} d\right)$ (50.5-54.9 Ma), Funing Formation $\left(E_{1} f\right)$ (54.9-65 Ma), the upper Cretaceous Taizhou Formation $\left(\mathrm{K}_{2} \mathrm{t}\right)$ (65-83 Ma), Chishan Formation $\left(\mathrm{K}_{2} \mathrm{c}\right)$, Pukou Formation $\left(\mathrm{K}_{2} \mathrm{p}\right)$, lower Cretaceous Gecun Formation $\left(\mathrm{K}_{1} \mathrm{~g}\right)$, and upper Jurassic Xihengshan Formation $\left(\mathrm{J}_{2} \mathrm{x}\right)$ while the Oligocene is missing.

Since the late Cretaceous, the Subei Basin has experienced five periods of tectonic movement (Qiu et al, 2006), that is, Yizheng (late $\mathrm{K}_{2} \mathrm{c}$ ), Wubu (late $\mathrm{E}_{1} \mathrm{f}$ ), Zhenwu (late $\mathrm{E}_{2} \mathrm{~d}$ ), Sanduo (late $\mathrm{E}_{2} \mathrm{~s}$ ), and Yancheng (late $\mathrm{N}_{2} \mathrm{y}$ ), and five regional unconformities have been formed (Table 1). The seismic

*Corresponding author. email: chenliq@joeco.com.cn

Received June 16, 2009 reflection layer $\mathrm{T}_{2}^{0}$ is an unconformity caused by the Sanduo event. Previous comprehensive study showed that: the Sanduo event has the biggest intensity; the sedimentation gap reaches $14 \mathrm{Ma}$; clear angle unconformities in the upper and lower strata were widespread in the Subei Basin; the upper strata were the Yancheng Formation, and the lower strata might be the Sanduo Formation, Dainan Formation, Funing Formation, even Mesozoic or Paleozoic (Liu et al, 2004; Chen, 1996;

Table 1 Seismic reflection layers and the corresponding tectonic events of the Subei Basin

\begin{tabular}{cccc}
\hline Strata & $\begin{array}{c}\text { Base seismic } \\
\text { reflection layer }\end{array}$ & $\begin{array}{c}\text { Tectonic } \\
\text { uplift event }\end{array}$ & $\begin{array}{c}\text { Geologic time, } \\
\text { Ma }\end{array}$ \\
\hline $\mathrm{Q}+\mathrm{Ny}$ & $\mathrm{T}_{2}{ }^{0}$ & Sanduo event & $38-24.6$ \\
$\mathrm{E}_{2} \mathrm{~S}$ & $\mathrm{~T}_{2}{ }^{3}$ & Zhenwu event & 50.5 \\
$\mathrm{E}_{2} \mathrm{~d}$ & $\mathrm{~T}^{0}$ & Wubu event & 54.9 \\
$\mathrm{E}_{1} \mathrm{f}_{4}-\mathrm{E}_{1} \mathrm{f}_{2}$ & $\mathrm{~T}_{3}{ }^{3}$ & & \\
$\mathrm{E}_{1} \mathrm{f}_{1}-\mathrm{K}_{2} \mathrm{t}$ & $\mathrm{T}_{4}{ }^{1}$ & Yizheng event & 83 \\
$\mathrm{~K}_{2} \mathrm{c}-\mathrm{K}_{2} \mathrm{p}$ & & & \\
\hline
\end{tabular}


Yang et al, 2003). Therefore, this study will focus on the erosion of the Sanduo event.

\section{Estimation of the erosion thickness of the Sanduo event}

Strata erosion is a common phenomenon in sedimentary basins, and erosion influences the generation, migration, and accumulation of oil and gas in basins, so the estimation of the level of erosion plays an essential role in the analysis of sedimentary basins. Currently, there are dozens of methods to estimate erosion thickness, including the mudstone interval transit time method, wave analysis method, trend surface analysis method, optimization method, stratigraphy method, natural gas equilibrium concentration method, basin subsidence history inversion method, sandstone porosity method, adjacent bed thickness ratio method, vitrinite reflectance method, palaeogeothermal method, sedimentation rate method, seismic-stratigraphic method, and the material balance method (Zhen, 1991; Dow, 1977; Pang et al, 1993; Guidish, 1985; Magara, 1981; Katz et al, 1988; He and Wang, 1989; Yin, 1992; Hao et al, 1988; Li and Li, 1996; $\mathrm{Li}, 1996)$. However, the above methods have limitations in their application due to special geological conditions, which promotes comprehensive research through multiple methods to accord with the geological facts.

According to the geological features and actual situation of the Subei Basin, we estimated the erosion of the unconformity surface caused by Sanduo event by using the mudstone interval transit time, vitrinite reflectance, and strata thickness trend extrapolation methods.

\subsection{Estimation of erosion in strata in a typical well}

\subsubsection{Interval transit time method}

As the most common method in the estimation of erosion thickness (Lu et al, 2009; Xu et al, 2008), the interval transit time method is not quite applicable when the thickness of new sedimentary strata is thicker than the denuded strata above the erosion surface. Mou et al (2000) think that it is not the thickness that plays a key role in estimating the erosion thickness, but whether the new strata above the erosion surface (unconformity) give the same pressure to the old strata as the eroded strata before erosion do. When the slope of compaction curves both above and below the erosion surface is equal, and the compaction law of the old strata does not change (compaction curve of the old strata is on the left side of the new strata), we can use the interval transit time method to estimate the erosion thickness. When the slope of strata compaction curves both above and below the erosion surface is not equal, and the compaction curve slope of the new strata is less than that of the old strata, the compacton law below the erosion surface has not been destroyed, and the new sedimentary strata thickness may be smaller than the erosion thickness, or may be greater. In both cases we can use the interval transit time method to estimate the erosion thickness. When the slope of the strata compaction curves both above and below the erosion surface is not equal, and the compaction curve slope of the new strata is more than that of the old strata, if the pressure given by the new strata to the old strata is less than that given by the eroded strata to the old strata before erosion (compaction curve of the old strata is on the left side of the new strata), the interval transit time method can be used. When un-compaction exists in the old strata (compaction curve of the old strata is on the right side of the new strata), the interval transit time method can not be used to estimate the erosion thickness (Fig. 1).

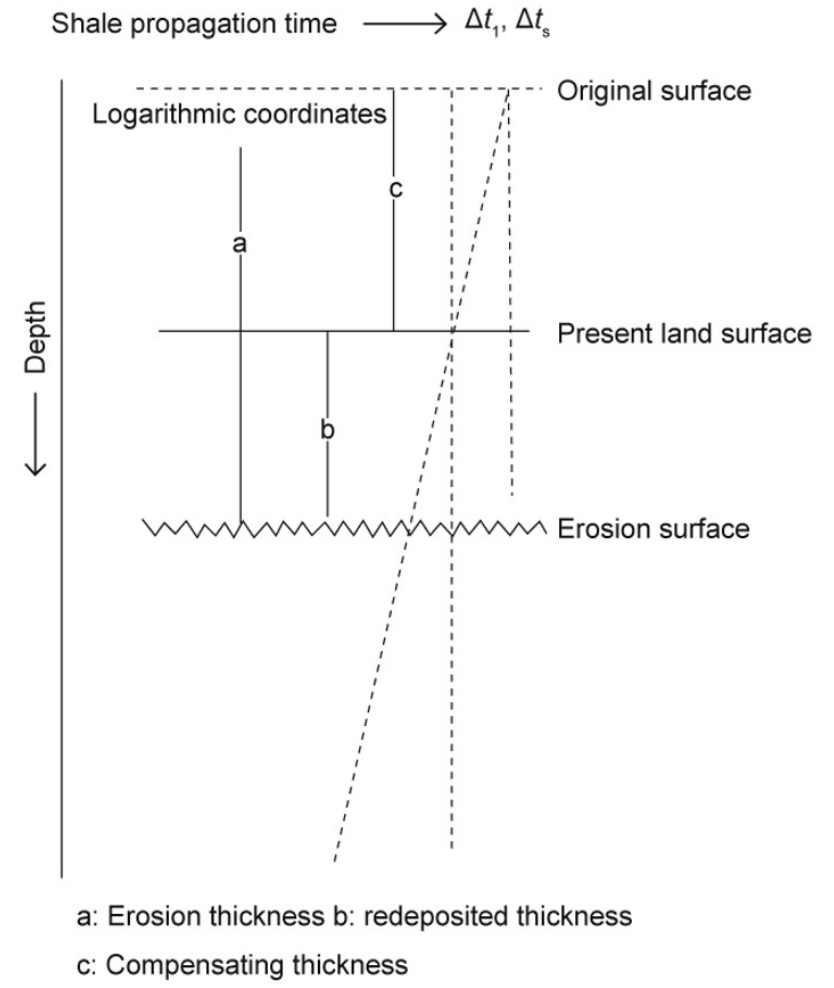

Fig. 1 Schematic diagram of the estimation of erosion thickness with the interval transit time method

After using the mudstone interval transit time data of eight wells in the Subei Basin to study the compaction law of the strata both above and below the erosion surface caused by Sanduo event, we found that in the Gaoyou Depression, Jinhu Depression, and Hongze Depression except in the deep sag area, the slope of the compaction trend line below the Sanduo Formation was obviously larger than that of the strata above the erosion surface, which showed that the pre-erosion compaction effect in these areas was not overshadowed by the late deposition. Based on this principle, no matter whether the new strata thickness was less than the thickness of erosion strata or not, the interval transit time method can be used to estimate the erosion thickness of this period. The results are shown in Table 2. Generally, from the late Eocene to Oligocene, Gaoyou, Jinhu, and Hongze depressions suffered strong erosion, and the total erosion thickness was 300-1,100 $\mathrm{m}$, but the erosion intensity among the tectonic units was extremely uneven. The erosion thickness of the slope-hollow transition zone was $300-500 \mathrm{~m}$, that of the slope zone was larger, generally $600-800 \mathrm{~m}$, and the low uplift area had the largest erosion thickness, ranging from $800 \mathrm{~m}$ to $1,100 \mathrm{~m}$. 
Table 2 Erosion thickness caused by Sanduo event of the controlling wells in the Subei Basin with the interval transit time method

\begin{tabular}{cccc}
\hline Computing method & Well No. & $\begin{array}{c}\text { Remained strata } \\
\text { thickness, }\end{array}$ & $\begin{array}{c}\text { Erosion thickness, } \\
\text { m }\end{array}$ \\
\hline & Yong25 & 1131 & 560 \\
& Wei8 & 321 & 800 \\
Interval transit time & Xuqian1 & 230 & 850 \\
& Zhe3 & 207 & 1150 \\
& Ying3 & 725 & 1050 \\
& Cui5 & 592 & 963 \\
& Shun1 & 1191 & 812 \\
\hline
\end{tabular}

However, the buried depth in the late Yancheng Formation of Hai'an Depression was generally too large, even larger than $2,000 \mathrm{~m}$, and the slope of the compaction trend line of the strata below the Sanduo Formation did not have a big difference from that of the strata above the erosion surface; that is, the pre-erosion compaction effect was overshadowed by the later deposition. Therefore, we can not use the mudstone interval transit time logging data to obtain the erosion thickness.

\subsubsection{Vitrinite reflectance method}

Vitrinite reflectance $\left(R_{\mathrm{o}}\right)$ is the most widely used index of the maturity degree of organic matter. Dow first proposed the method of estimating the level of erosion through vitrinite reflectance (Dow, 1977; He and Wang, 1989; Tong and Zhu, 2006), that is, using the difference of $R_{\mathrm{o}}$ between adjacent layers to estimate the amount of erosion.

Generally, $R_{\mathrm{o}}$ changes in the same trend as depth, but when faults or magma invasion exist in the strata, or the geothermal gradient and thermal conductivity change significantly, or the rock mass has local heat source, $R_{\mathrm{o}}$ will change suddenly. Besides, strata erosion can also cause the discontinuity of $R_{\mathrm{o}}$. There are two ways to estimate erosion thickness using $R_{\mathrm{o}}$. First, $R_{\mathrm{o}}$-depth curves of the strata above and below the erosion surface can be drawn respectively, and then we can obtain erosion thickness by a graphical method. Second, erosion thickness can be obtained through solving the relation formulas between $R_{\mathrm{o}}$ and depth. We can find that the two ways have the same basic principle, and both need sufficient $R_{\mathrm{o}}$ data.

Although it is easy to obtain $R_{\mathrm{o}}$ data and calculate, the $R_{\mathrm{o}}$ method still has the following shortcomings. Firstly, we should ensure that the abrupt change of $R_{\mathrm{o}}$ is caused by erosion. Although there are some methods to judge, it remains a very difficult task. Secondly, when the depth increases, $R_{\mathrm{o}}$ below the unconformity surface does not have an obvious change, but $R_{\mathrm{o}}$ above the unconformity surface increases rapidly. After certain geological time, the difference between two $R_{\mathrm{o}}$ values will decrease to zero eventually. This is the socalled "annealing" phenomenon.
According to the above method with BASIMS simulation software, we selected five wells in the Gaoyou Depression to estimate the erosion thickness. The results show that the strata erosion thicknesses are between $600 \mathrm{~m}$ to 1,200 m (Table $3)$. Because the number of wells after the Sanduo event in the Subei Basin with $R_{\mathrm{o}}$ test data is small, using this method in the whole basin is limited.

Table 3 Erosion thickness of Sanduo event of the controlling wells in the Subei Basin with the $R_{\mathrm{o}}$ method

\begin{tabular}{cccc}
\hline Computing method & Well No. & $\begin{array}{c}\text { Remained strata } \\
\text { thickness, } \mathrm{m}\end{array}$ & $\begin{array}{c}\text { Erosion thickness, } \\
\mathrm{m}\end{array}$ \\
\hline & Zhen86 & 1131 & 600 \\
$\begin{array}{c}R_{\mathrm{o}} \text { forward } \\
\text { numerical modelling } \\
\text { method }\end{array}$ & Sha14 & 882 & 750 \\
& Xugu1 & 754 & 950 \\
& Xingcan1 & 205 & 1130 \\
\hline
\end{tabular}

\subsection{Estimation of erosion thickness of the Sanduo event with the integrated strata trend extrapolation method}

At present, two-dimensional seismic data cover the entire basin, and three-dimensional seismic data in the Gaoyou, Jinhu, and Hai' an depressions connect together, which create the conditions for using the trend analysis method to estimate the strata erosion thickness in the entire region based on seismic data. As a result, we used the interval transit time method, vitrinite reflectance method, and strata thickness trend extrapolation method to estimate the erosion thickness in the Sanduo period.

The strata thickness trend extrapolation method is based on the relative continuity and regularity of sedimentary strata, and uses the seismic data for strata trend extrapolation. The principle is that the strata thickness often has a specific variation rule in the horizontal direction. According to the interpolation points of non-erosion strata thickness and the sedimentary boundary (zero thickness) or according to the extrapolation of two non-erosion strata thicknesses, the eroded strata thickness can be estimated. The precondition is assuming that the strata have uniform thickness or change evenly before erosion. The procedure to estimate the erosion thickness of Sanduo event is as follows:

1) We used the mudstone interval transit time and vitrinite reflectance methods to calculate the amount of erosion in twelve controlling wells in the slope region (Table 2 and 3). On the basis of the interpretation of the unconformity surface, we chose a seismic section with the known erosion passing the controlling well points as the first section to carry out the estimation of erosion quantity.

2) We selected the isochron curve reflecting the sedimentary trend in the late Sanduo period as a virtual reference line (such as Sanduo strata inclined plane). After 
flattening the $\mathrm{T}_{2}{ }^{0}$ interpreted layer, with reference to the virtual line, combined with sedimentary trend, according to the erosion level of the controlling well points, we began to estimate the erosion quantity (Fig. 2).

3) According to the cross intersection law, we carried out the interpretation, closing, estimation of the erosion surface in the region gradually (Figs. 3 and 4).

4) The buried depth of unconformity minus the depth of the estimated erosion surface was the erosion thickness of the Sanduo event (Fig. 5).

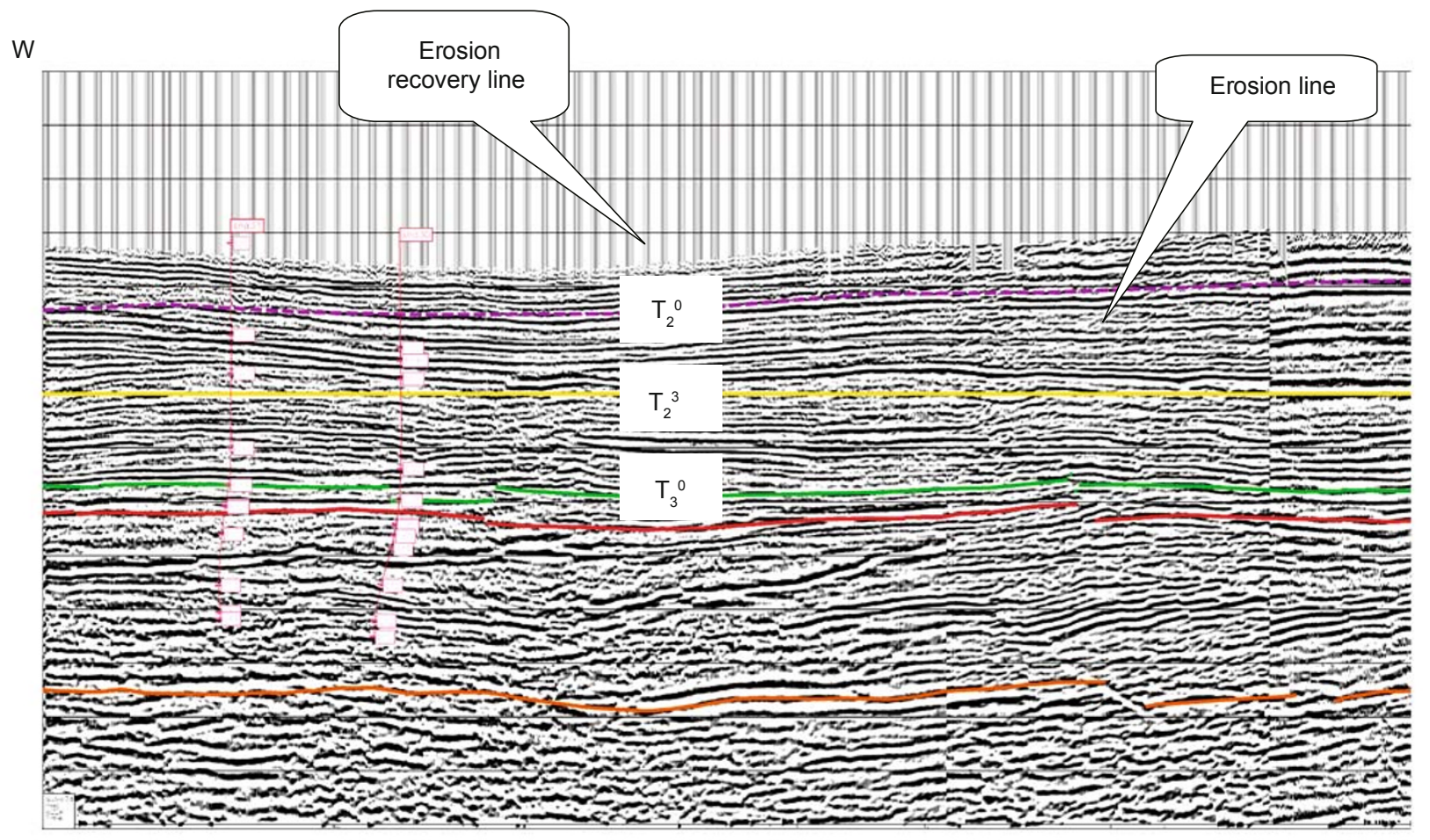

Fig. 2 Interpretation section of erosion thickness estimation of seismic line G203 in the Subei Basin

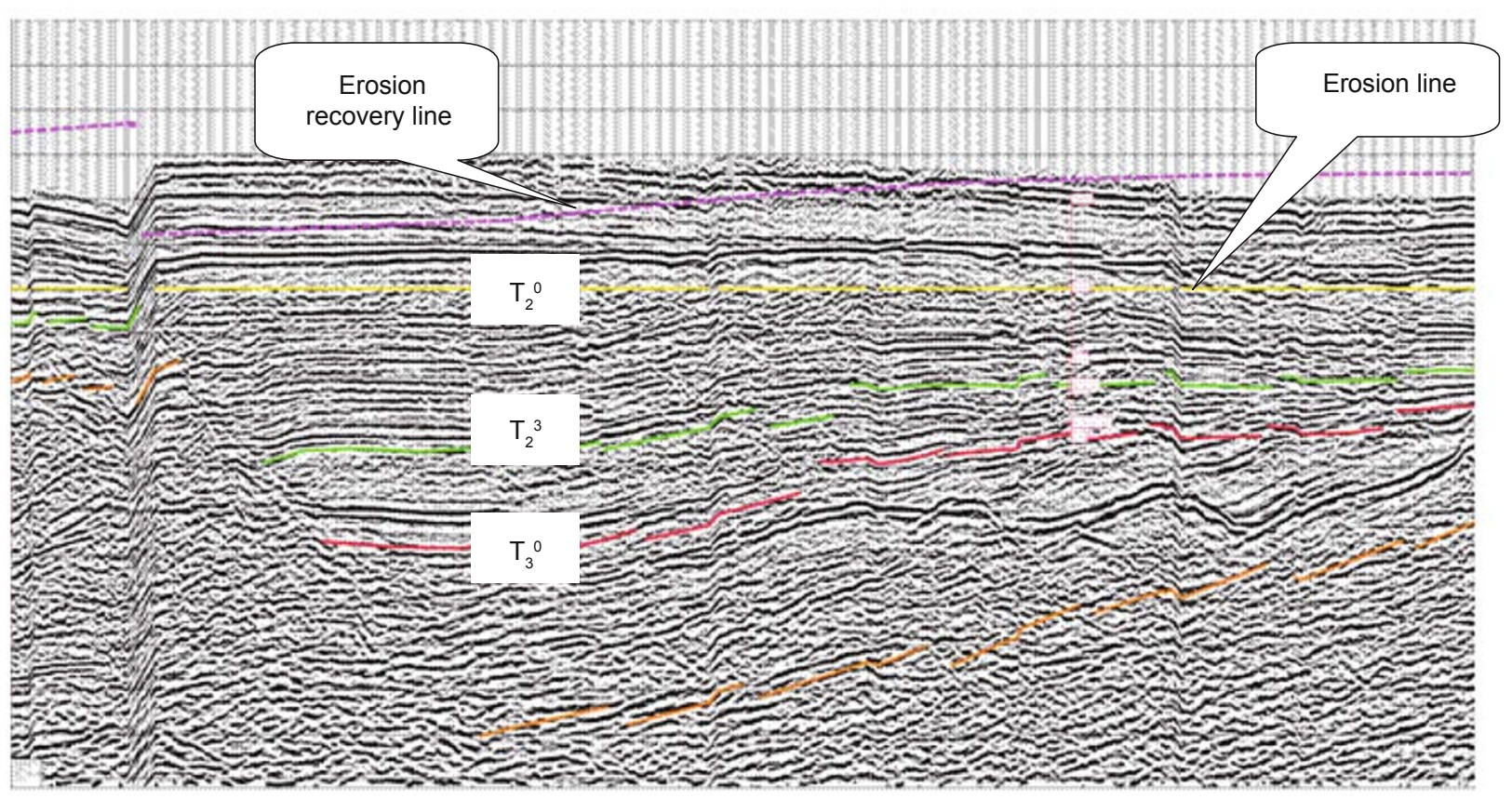

Fig. 3 Interpretation section of erosion thickness estimation of seismic line G44 in the Subei Basin 


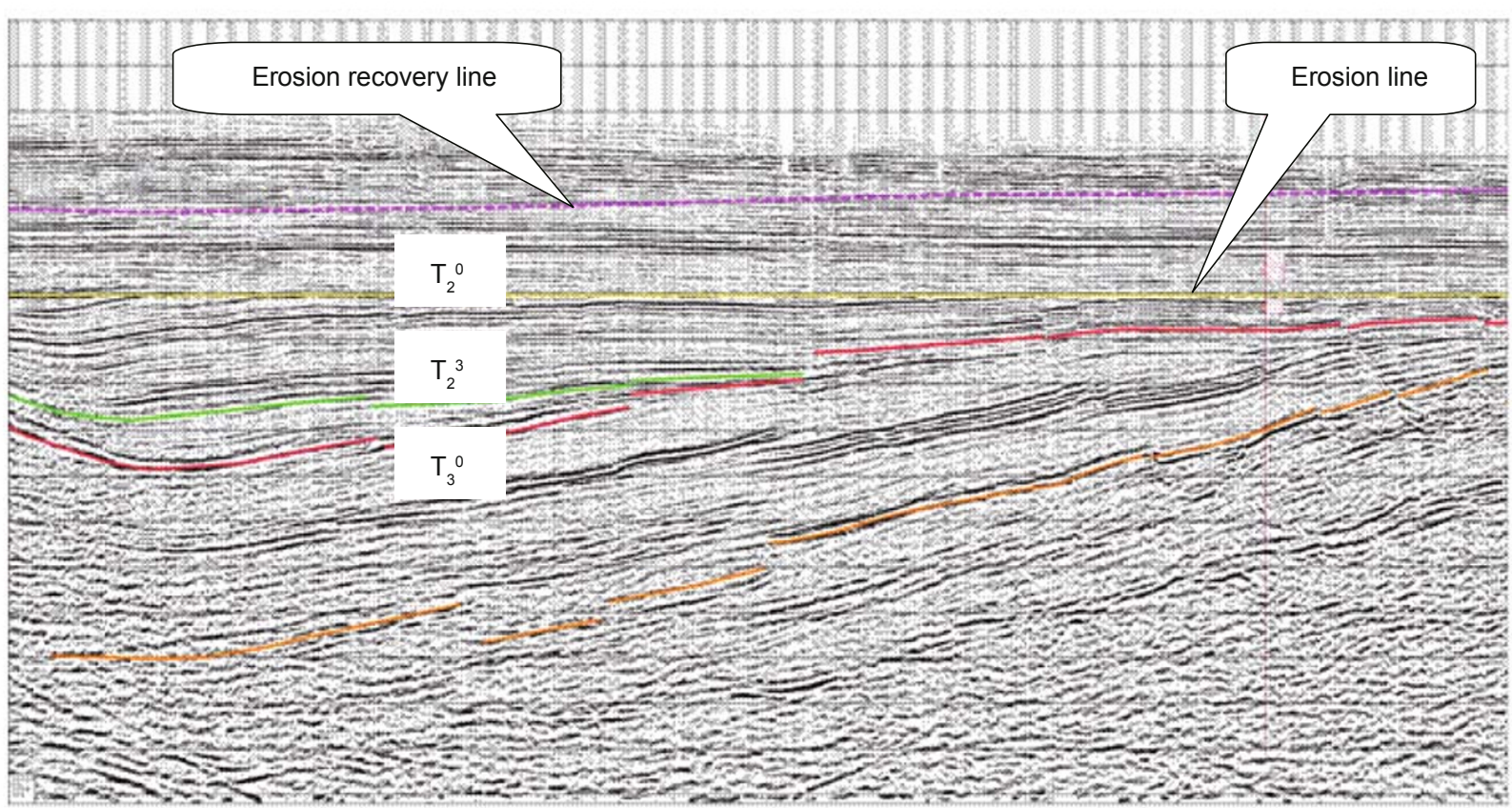

Fig. 4 Interpretation section of erosion thickness estimation of seismic line G108 in the Subei Basin

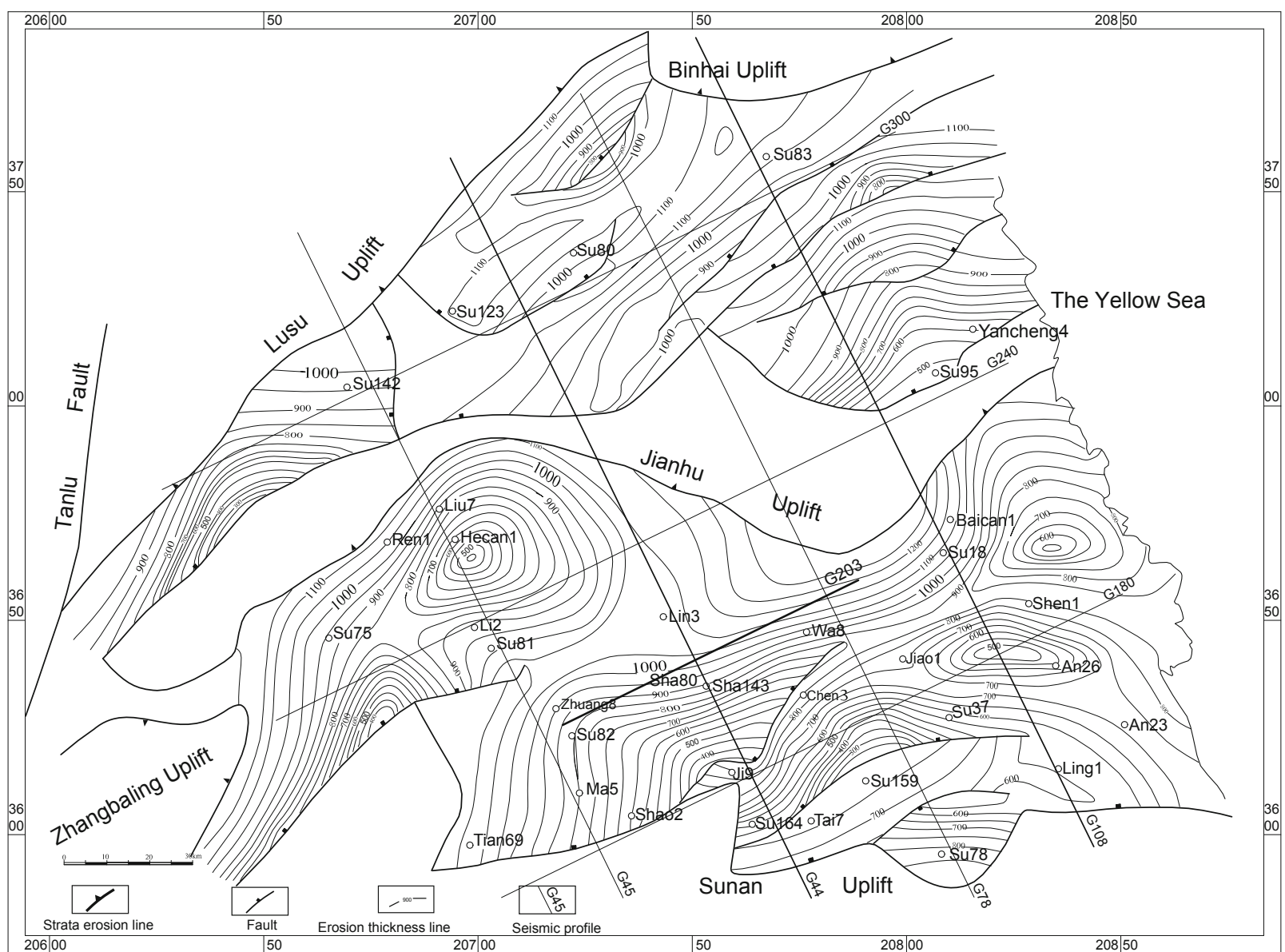

Fig. 5 Map showing the strata erosion thickness of the Subei Basin in the Sanduo event 
The results show that the largest amount of erosion of the Sanduo event in the Subei Basin is between 1,000 $\mathrm{m}$ and $1,200 \mathrm{~m}$, mainly located in depressions around the Jianhu Uplift; the deep hollow area has the least erosion, generally about $300-600 \mathrm{~m}$; the erosion in the slope area is about 600 $900 \mathrm{~m}$; the erosion in the south is relatively smaller than that in the northern part. From the eastern part of the Gaoyou Depression to the Hai'an Depression, the erosion quantity of Sanduo event is generally less than the strata thickness of late sedimentation.

\section{Conclusions}

1) By using the mudstone interval transit time and vitrinite reflectance methods on data from twelve typical wells, it can be concluded that the Gaoyou, Jinhu, and Hongze depressions suffered strong strata erosion from the late Eocene to Oligocene, and the total strata erosion thickness was 3001,100 m. Different tectonic units in the same depression have extremely uneven erosion intensity; the low convex regions have the maximum erosion thickness, amounting to $800-1,100 \mathrm{~m}$; the slope regions have an erosion thickness of generally $600-800 \mathrm{~m}$ and the erosion thickness of the slopehollow transition zone is $300-500 \mathrm{~m}$.

2) We used the strata thickness trend analysis method combined with the interval transit time method and vitrinite reflectance method to estimate the erosion thickness in the Sanduo period, and the results show that the greatest level of erosion of the Sanduo event in the Subei Basin is between $1,000 \mathrm{~m}$ to $1,200 \mathrm{~m}$, mainly located in depressions around the Jianhu Uplift, the deep hollow area has the least erosion, generally about $300-600 \mathrm{~m}$, and the erosion in the slope area is about $600-900 \mathrm{~m}$.

3) The erosion in the south is relatively smaller than that in the northern part. From the eastern part of the Gaoyou Depression to the Hai'an Depression, the erosion of Sanduo event is generally less than the strata thickness of later sedimentation. It shows the heterogeneous intensity of the Sanduo event, and the activity intensity of the western region is greater than that of the eastern region.

\section{References}

Chen A D. Structural setting for "shallow" maturation of the lower tertiary source rocks in Subei Basin. Petroleum Exploration and Development. 1996. 23(4): 6-10 (in Chinese)

Dow W G. Kerogen studies and geological interpretation. Journal of Geochemical Exploration. 1977. 7(2): 79-99

Guidish T M, Kendall C G St C, Lerche I, et al. Basin evaluation using burial history calculations: an overview. AAPG Bulletin. 1985. 69(1): 92-105

Hao S S, He Z Y, Gao Y B, et al. An optimization method for restoration of eroded formation thickness. Acta Sedimentologica Sinica. 1988. 6(4): 93-99 (in Chinese)

He S and Wang Q L. The eroded thickness reconstructed by vitrinite reflectance. Geological Review. 1989. 35(2): 119-125 (in Chinese)

Katz B J, Pheifer R N and Schunk D J. Interpretation of discontinuous vitrinite reflectance profile. AAPG Bulletin. 1988. 72(8): 926-931

Li M C and Li W. A study of natural gas diffusion by equilibrium concentration-a new method for diffusion quantitative modelling. Natural Gas Industry. 1996. 16(1): 1-5 (in Chinese)

Liu X P, Yang L G and Xu J. Restoration of Eocene erosion thickness in Gaoyou Sag. Xinjiang Petroleum Geology. 2004. 25(2): 128-130 (in Chinese)

Li W. Summary of reconstruction of strata denudation thickness. China Offshore Oil and Gas. 1996. 10(3): 167-172 (in Chinese)

Lu X S, Ma S F and Yang G L. Erosion thickness reconstruction of Sanduo Formation and its significance in Jinhu Sag, Subei Basin. Journal of Southwest Petroleum University. 2009. 31(4): 13-17 (in Chinese)

Magara K. Compaction and Migration of Hydrocarbon (translated by Chen H L, Di S X, Tang X Y). Beijing: Petroleum Industry Press. 1981 (in Chinese)

Mou Z H, Chen Z Y, Lu T Q, et al. The recovery of Mesozoic formation erosion thickness in the north margin of Qaidam Basin. Petroleum Exploration and Development. 2000. 27(1): 35-37 (in Chinese)

Pang X Q, Chen Z M and Chen F J. Numerical Simulation of Geologic History, Thermal History, Hydrocarbon Generation and Expulsion History and Quantitative Assessment of Hydrocarbon Source Rock in Oil and Gas Bearing Basins. Beijing: Geological Publishing House. 1993. 16-21 (in Chinese)

Qiu X M, Liu Y R and Fu Q. Sedimentary Evolution and Sequence Stratigraphy from the Upper Cretaceous to Tertiary in Subei Basin. Beijing: Geological Publishing House. 2006. 7-11 (in Chinese)

Tong Y M and Zhu G H. Several important problems on estimating the thickness of eroded strata by vitrinite reflectance. Journal of Oil and Gas Technology. 2006. 28(6): 197-199 (in Chinese)

Xu T W, Wang Y M, Wei S J, et al. Restoration of Eocene erosion thickness of Sanduo event in the Subei Basin. Journal of Oil and Gas Technology. 2008. 30(6): 56-60 (in Chinese)

Yang L G, Lu Y and Chen P Y. Analysis of denudation rate between early and late tertiary systems of Gaoyou Depression. Journal of Jianghan Petroleum Institute. 2003. 25(Supplement): 33 (in Chinese)

Yin T F. A multi-information method for computing erosional thickness. Petroleum Exploration and Development. 1992. 19(5): 42-47 (in Chinese)

Zhen B Q C. The Geological Model of Oil Traps (translated by Tong $\mathrm{X} \mathrm{G}$ and Jia C Z). Wuhan: China University of Geosciences Press. 1991. 83-98 (in Chinese)

(Edited by Hao Jie) 